\title{
Profanar cuerpos / profanar naciones. Acerca de La emancipada como novela fundacional de la literatura ecuatoriana*
}

Fecha de recepción: 28 de marzo de 2016

Fecha de aprobación: 30 de junio de 2016

\section{Resumen}

Este trabajo pretende realizar una lectura alternativa a aquello que podemos entender como representación del cuerpo, con el fin de problematizar conceptos como los de novela fundacional y literatura nacional. Se espera formular otros modos de mirar aquellas imágenes corporales que han sido relegadas bajo los escombros ocasionados por el empeño de construcción de una historia literaria, específicamente la historia de la literatura ecuatoriana. En el caso de La emancipada de Miguel Riofrío (1863), considerada la primera novela ecuatoriana, sugiero pensar: si el cuerpo muerto y en estado de descomposición de su protagonista, Rosaura, no logra tener una apariencia decente, ¿cómo se entiende que sea ese cuerpo el que se instaure como la imagen de la consolidación de un corpus literario? ¿Cómo puede ser viable una historia literaria nacional que se funda sobre la representación de una imagen corporal desmembrada e imposible?

Palabras clave: literatura ecuatoriana, cuerpo y literatura, literatura y nación, imagen y literatura.

Citar: Marín Lara, K. (julio-diciembre de 2016). Profanar cuerpos / profanar naciones. Acerca de La emancipada como novela fundacional de la literatura ecuatoriana. La Palabra, (29), 89-102. doi: http://dx.doi.org/10.19053/01218530. n29.2016.5703

\section{Karina Marín Lara}

Magíster y candidata al Doctorado en Literatura por la Universidad de Los Andes. ks.marin87@uniandes.edu.co.

* Artículo de reflexión. Este trabajo forma parte del proyecto de tesis: "El cuerpo imposible: (des)figuraciones de la nación en la literatura ecuatoriana". 


\section{la palabra}

\section{Profaning Bodies / Profaning Nations. On La emancipada [The Emancipated One] as Foundational Novel in Ecuadorian}

\section{Literature}

\section{Abstract}

This work aims at providing an alternative reading about what we can understand as representation of the body, in order to question notions such as foundational fiction and national literature. My goal is to formulate other ways to examine images of the body that have remained under the rubble in the effort to construct a history of literature, specifically Ecuadorian literary history. Taking into account the first Ecuadorian novel, La emancipada (1863), written by Miguel Riofrío, I suggest: if Rosaura's dead body, described as a putrefied body, cannot exhibit a respectable appearance, how can we understand this body as the starting point for the consolidation of a literary corpus? How can a national literary history be possible, when it is constructed over the representation of this dismembered and unviable body image?

Keywords: ecuadorian literature, body and literature, literature and nation, image and literature.

\section{Profaner les corps / profaner les nations. Sur La emancipada [La libertaire] comme roman national de la littérature équatorienne}

\section{Résumé}

Nous voulons réaliser dans ce travail une lecture alternative de ce que nous comprenons comme représentation du corps, afin de problématiser des concepts comme ceux du roman fondationnel et de littérature nationale. On voudrait formuler autres définitions des images corporelles qui ont été reléguées par la volonté de construction d'une histoire littéraire, notamment l'histoire de la littérature équatorienne. Dans « La emancipada » de Miguel Riofrío (1863), considéré comme le premier roman équatorien, nous nous demandons si le corps mort en état de décomposition du personnage principal, Rosaura, ne réussirait pas á avoir une apparence convenable. Comment peut-on comprendre que se soit ce corps qui instaure l'image de la consolidation d'un corpus littéraire ? Comment peut-on construire une histoire littéraire nationale fondée sur la représentation d'une image corporelle démembrée et impossible?

Mots-clés : littérature équatorienne, corps et littérature, littérature et nation, image et littérature. 


\section{"La emancipada [...] es un relato nada desdeñable, una moralidad que poco tiene de novela.» \\ Bruno Sáenz Andrade, "Historia de las literaturas del Ecuador"}

El epígrafe que antecede está determinado por un juicio de valor. Juicio contradictorio, por cierto, que traigo a colación porque logra condensar las opiniones en torno a este relato de 1863, considerado hoy en día como la primera novela ecuatoriana. ¿Cómo es posible que un relato que nada tiene de novela sea tomado en cuenta, sin embargo, como la obra inaugural de toda una tradición? ¿Cómo se puede no desestimar el relato, no menospreciarlo $\mathrm{y}$, sin embargo, afirmar que más que de una novela se trata de una «moralidad»? El crítico y poeta Bruno Sáenz, a quien le fue encomendada la labor de referir la literatura de la República durante el período 1830-1895 para la Historia de las literaturas del Ecuador, se encarga de plasmar esta contradicción: confirma sus logros narrativos y psicológicos, la riqueza del diálogo epistolar; incluso afirma que «[E]s encomiable la intención feminista y antiautoritaria». Sin embargo, asevera enfáticamente: «falta, únicamente, la novela» (Sáenz, 2000, p. 84).
La emancipada, obra del lojano Miguel Riofrío, publicada como folleto en el periódico $L a$ Unión, fue redescubierta por la crítica en la década de 1950, casi cien años después de su aparición, y su primera publicación del siglo XX data de 1974. Hasta ese entonces, Cumandá (1879), la novela romántica de Juan León Mera, ocupaba el lugar inaugural de la novelística ecuatoriana. Sáenz, que a pesar de sus reparos inicia su recuento histórico con una referencia a $L a$ emancipada, alega sin embargo la superioridad de la obra de Mera: "Cumandá señala Sáenz- sigue siendo, a la espera de una no imposible pero acaso improbable exhumación, el punto de partida para el estudio del género.» (p. 84). En otras palabras, Sáenz tiene una intención muy específica y paradójica, al tiempo que deslegitima el valor literario del trabajo de Riofrío y protege el lugar inaugural de la novela de Mera: esto es, pretende reservar, por si acaso, el lugar honorable de la obra precursora para aquella que pueda certificar en el calendario de la nación su edad de nacimiento $\mathrm{y}$, en consecuencia, la madurez de un proyecto literario nacional.

Ahora bien, los criterios por los que, para Sáenz, esta novela carece de lo que requiere una novela, no son enfáticos ni claros; precisamente porque su afirmación está rodeada de imprecisiones, sus argumentos hacen pensar que entre Cumandá y $L a$ emancipada es preferible quedarse con la primera, aunque también aquella haya sido estéticamente deslegitimada ${ }^{1}$. La obra de Riofrío es insuficiente para los ojos de Sáenz, porque además carece de la extensión y las descripciones detalladas, sobre todo del paisaje, que hacen de Cumandá una narración de largo aliento (p. 84). Se trata de reparos de tipo formal que no quedan del todo claros. Sáenz trata, sin embargo, de no contradecir a críticos como Hernán Rodríguez Castelo, Antonio Sacoto y Alejandro Carrión, en cuyos argumentos, aunque tampoco se rescatan virtudes formales de la novela, siempre se evalúa positivamente el documento por sus circunstancias históricas y especialmente por constituir "un vigoroso alegato 
en favor de la mujer" (Sacoto, 1983, p. 8), "un aporte auténtico, sin embargo, para constatar, desde entonces, una vertiente ideológica progresista, la más poderosa en nuestra narrativa" (Donoso, 2003, p. 9). De igual manera, uno de los argumentos más comunes tiene que ver con la fecha de aparición del texto. Por ejemplo, luego de hacer un recorrido por las fechas de publicación de algunas novelas fundacionales latinoamericanas (El periquillo sarniento, de 1816; El matadero, de 1837, etc.), Antonio Sacoto afirma que el descubrimiento de $L a$ emancipada «llena un vacío literario en el Ecuador», criterio que le adjudica a la posibilidad de poder decir «que también tenemos nuestra novela representativa de este período y que nuestra incursión en la novela hispanoamericana no es tan rancia y tardía como nos habíamos imaginado con Cumandá $[\ldots] \gg\left(\right.$ p. 8) ${ }^{1}$. Porque, como he dicho, la premura no es por leer la novela, sino por comprobar y resaltar las ventajas de su fecha de nacimiento. Por eso, cuando ya en el año 2000 Bruno Sáenz aboga por una «no imposible pero improbable exhumación» de alguna novela que rescate el género, está declarando no sin cierta desesperanza que es necesario que aparezca una novela literariamente mejor a $\mathrm{Cu}$ mandá y a La emancipada que, a la vez, cumpla con el requisito fundamental de haber nacido antes que ambas. Espera, para decirlo de algún otro modo, que esa exhumación recupere un mejor producto literario, más verosímil, mejor formado en términos de una tradición estética hegemónica. Mientras tanto, el mensaje entre líneas es que la historia de la literatura ecuatoriana debe conformarse con lo que hay.

Mi propuesta, que se contrapone a la teleología con la que críticos como Sáenz y Sacoto se identifican, asume la idea de la exhumación, no como un desesperado trabajo de archivo para tratar de desempolvar la novela perdida, sino como metodología para desentrañar del interior de la misma novela las imágenes que imposibilitan su correspondencia con un proyecto nacional. Como lo veo, la necesidad que tienen la historia y la crítica literarias de fijar un punto de partida que le dé legitimidad a la edad de esa literatura, implica una estrategia violenta, una especie de catástrofe, que esconde bajo sus escombros los detalles sobrecogedores de un pasado contradictorio, y que a la vez niega la posibilidad de una lectura que pueda ir más allá del discurso nacional y de la consolidación de una tradición. En respuesta, lo que propongo es leer sin buscar defini- ciones ni finalidades, sino a la espera de encontrar bajo los escombros alguna imagen que nos conmueva hoy, cuando parece que ya todo está dicho, cuando pensamos que la historia ya está definida.

No planteo, sin embargo, tratar de resolver las tensiones que provoquen esas imágenes, porque hacerlo implicaría un intento por incorporarlas a la historia nacional. El fin es, en cambio, llevar a cabo una forma de lectura que nos mueva a entenderlas y a reconocerlas por la materialidad que revelan, por ese «singular espesor» al que hace referencia Gisella Catanzaro (2011) en su crítica sobre la historia y la nación, espesor que opera como característica de aquello que vuelve y persiste, pese a la violencia. Como ha dicho Walter Benjamín (1989), «al pasado solo puede retenérsele en cuanto imagen que relampaguea, para nunca más ser vista, en el instante de su cognoscibilidad» (p. 180). De manera que, volviendo la vista hacia el pasado, retándola a no tratar de hallar aquello del futuro que siempre aqueja a cualquier teleología, esas imágenes relampagueantes no siempre cómodas para los ojos pueden hacer que reactivemos la memoria como estrategia de resistencia ante la violencia que entrañan los discursos y las prácticas del pasado per-

\footnotetext{
Vale recordar que la edición de 1983, presentada por Sacoto, lleva por título La emancipada. Primera novela ecuatoriana.
} 
petuados en los discursos y las prácticas del presente. Se trata, entonces, de una mirada que no busca encontrar en esas imágenes solamente los significados de su poder de representación, sino ante todo su poder de afectación, lo que conlleva una mirada/lectura que va más allá de la formalidad y la minuciosidad de la decodificación: una mira$\mathrm{da} /$ lectura que se conmueve de manera finalmente ética y política ante cada huella, ante cada herida.

Propongo, por lo tanto, remover los escombros provocados por esa estrategia violenta -en primer lugar, la de la constitución del canon como una imposición histórica- y exhumar las imágenes que yacen a la espera de miradas que se resistan al tiempo, especialmente, al tiempo de la nación. Pero, aún más, porque la resistencia de esas miradas debería pasar por la conciencia de la necesidad de mirar de otro modo -que es, en definitiva, leer de otro modo-; propongo que las imágenes a ser exhumadas sean precisamente las de cuerpos, de marcas corporales, de órganos corporales que quizá puedan ayudarnos a poner en crisis la usual lectura orgánica, lineal y unificadora del corpus de la literatura nacional; o, para decirlo de otro modo, sugiero un método de exhumación de cicatrices, desfiguraciones $\mathrm{y}$ desmembraciones corporales que, como se espera demostrar, logran salir a la superficie para imposibilitar la consecución de lo homogeneizador, pero, a la vez, para presentar nuevas opciones éticas de resistencia histórica y de reconocimiento en la diversidad.

Dicho esto, debo aclarar que no se trata de construir un nuevo modo de metaforización del cuerpo. La historia de la literatura, restringida a la nación como modo y espacio paradigmático para su clasificación y desarro1lo, se consolida sobre la idea de lo orgánico desde el siglo XIX, por lo que las analogías de las ciencias naturales son claramente asumidas por ese afán historizador. De ese modo, el cuerpo como idea moderna, en cuanto materialidad biológica, se convierte en herramienta metafórica de esa tradición, y ayuda a delimitar esa historia en torno a nociones de identidad y carácter nacionales, que deben funcionar de forma orgánica. En otras palabras, la metáfora corporal apoya la configuración de un 'corpus literario' que tiene por fin referir la identidad de una nación. Sin embargo, para decir ese cuerpo, hay que recurrir a su fragmentación: es imposible abarcarlo todo, pues la única manera de aludir al cuerpo es decir sus partes, mostrar el detalle, como cuando se lee «era de complexión recia, seco de carnes, enjuto de rostro [...]» (Cervantes, 1605, p. 28). Por lo tanto, para pretender decir el cuerpo ideal de la nación, ese que actúa como metáfora o mejor, como ha dicho Gisela Catanzaro, como "materia espiritualizada", es preciso entender que lo que se dice de él es aquello que lo contradice como unidad, que lo desarticula, que lo des-metaforiza ${ }^{2}$. En otras palabras, lo que hace la historia que legitima los textos de un corpus -en este caso, los de la literatura ecuatoriana, como La emancipada - es asumir esos cuerpos que no pueden formar parte de la nación para, por contraste, consolidar el dominio de una sola verdad, es decir, el poder del cuerpo idealizado. No existe otro modo de nombrar el cuerpo viable de la nación -el cuerpo mestizo, masculino, productivo, saludable- que no sea el de re-

\footnotetext{
2 Así, afirmar que lo fundacional en la literatura se relaciona con un cuerpo sano y solemne implica comprender los modos en los que opera el lenguaje para tratar de decir el cuerpo que se pretende idealizar. Por ejemplo, en una novela de la tradición argentina como El matadero, en donde se describen también cuerpos desmembrados, la estrategia de Echeverría para provocar rechazo ante una realidad -la del gobierno de Rosas- que la ciudad letrada argentina percibe como barbarie, es la de brutalizar la realidad rosista a partir de las imágenes corporales de desmembración. Esos cuerpos desmembrados pueden ser una analogía de lo no deseado, de lo abyecto, pero además son lo único de cuerpo que puede decirse. De ese modo, se logra fijar por contraste en el lector la ilusión de aquella utopía por la que se debe luchar en contraposición a la realidad de la barbarie. El paradigma es el cuerpo sano, normal, los cuerpos abyectos -que sí se dicen, porque se dicen sus huellas, sus marcas- sirven para enfatizar esa utopía.
} 
currir a los cuerpos inviables, a su fragmentación en la palabra. La búsqueda del cuerpo ideal es una labor de antemano frustrada, porque su imposibilidad de materialización que se traduce en su imposibilidad de ser imaginado y escuchado, solamente posibilita un juego de simulación, en el que pretendemos ver algo que no es más que la ilusión de esa dinámica histórica que hace que el proyecto nacional se eleve por sobre la carne (Catanzaro, 2011). Por eso, propongo que esas huellas de cuerpos han quedado sepultadas debajo del esfuerzo por resaltar una materia digna de entrar en la Historia y de esconder lo abyecto. Son esas huellas, sobre-expuestas o sub-expuestas por la Historia, las que sugiero exhumar de entre los escombros ocasionados por el afán nacionalizador. En La emancipada, como veremos, la imposibilidad no está en la analogía, sino en la materialidad que se desprende de lo que las imágenes del cuerpo de Rosaura pueden provocar en el lector que está dispuesto a leer deteniendo y desordenando esa organicidad.

\section{Imágenes en trozos}

Las marcas del cuerpo de Rosaura, la protagonista de $L a$ emancipada, son marcas de un cuerpo que asedia. Desde el inicio de la novela, la descripción de sus gestos, de sus facciones, de su ropa, nos permite tener a Rosaura ante nuestros ojos. Por eso, es muy fácil enamorarse de Rosaura, como se enamora uno de los grandes ojos de Emma Bovary, los ojos que Charles descubre al inicio del relato. Sin embargo, lo que vemos al final del texto de Flaubert es el cuerpo de una mujer, el de Emma, en estado de descomposición.

Sucede igual con Rosaura: hacia el final, se trata de un cuerpo en trozos que rompe con la imagen altiva, desafiante y heroica del resto de la novela, trayendo, sin embargo, la imagen de lo aún vivo, amenazante. Como sugiere Georges Bataille, solamente cuando la descomposición de la carne se ha consumado, y ya no es posible que emane vida de ese cuerpo, ese cuerpo deja de producir asco. Dice Bataille (2005): «Los huesos blanqueados ya no abandonan a los supervivientes a la amenaza viscosa y pegajosa que no puede sino provocar asco. Esos huesos ponen fin al emparejamiento fundamental entre la muerte y esa descomposición de la que brota una vida profusa» (p. 60). Así, los huesos blanqueados de los que habla Bataille logran apaciguar el asco e introducen «una primera apariencia decente -solemne y soportable- de la muerte» (p. 60). Luego, una vez dada esa solemnidad, la muerte se transforma en vehículo para la inmortalidad: los cuerpos solemnes se eternizan, se narran, se idealizan, mientras los cuerpos del asco quedan relegados al olvido de la mirada y de la historia.

¿Por qué sentimos asco? Nussbaum (2008) explica que el asco es una emoción asociada con la vergüenza, y la atención que esta pone en las insuficiencias corporales que amenazan al sujeto ante la idea de contagio. Asimismo, esta autora afirma que:

[...] también reaccionamos con asco ante los despojos y las cosas corruptas, es decir, ante lo que, según esta misma imagen, nos haría mortales y corruptos si lo comiéramos. De este modo, el asco conjura tanto la animalidad en general como esa mortalidad de nuestra condición animal que tanta aversión nos causa (p. 237).

El asco es, entonces, una emoción que define los límites del cuerpo, que se vincula con nuestro temor a morir, «con nuestra vulnerabilidad a la descomposición» (p. 237). Volviendo con Bataille, entonces, los huesos blanqueados construyen héroes que ansiamos exhumar y admirar, que queremos fijar para legitimar la inmortalidad del cuerpo de la nación. Los cuerpos descompuestos, en cambio, detonan el miedo a contagiarse, a convivir, a conmoverse como posibilidades de la intrascendencia. 
Rosaura es la polémica joven mujer que, luego de rebelarse ante su padre y ante la institución matrimonial, huye el día de su boda hacia la ciudad y, tras la espera frustrada del hombre al que ama, dedica su vida a los placeres y a la prostitución. De un modo vertiginoso, el personaje va mutando hasta llegar al suicidio como su única salvación. El relato de su muerte, más allá de los motivos esbozados a lo largo de la corta novela, se circunscribe especialmente a la descripción de la podredumbre de sus órganos corporales, exhibidos mediante el acto de la disección llevado a cabo por un médico y un estudiante de medicina, en presencia de algún abogado. Luego, la narración dará pistas de cómo ocurrieron los hechos, mediante la puesta en escena de un intercambio epistolar entre Rosaura y Eduardo, su antiguo amor, por quien ella decidió en vano emanciparse. Ya en esas cartas -0 , mas bien, debido a ellas-, Rosaura insinuará su intención de quitarse la vida. Estamos, entonces, ante una primera tensión: el cuerpo desmembrado y putrefacto de Rosaura, que es diseccionado antes de leer las cartas, es disimulado, ocultado si se quiere, por el relato del intercambio epistolar. Con la lectura de esos documentos, se cuenta, se teje una historia que cubre y viste de sentido la imagen aterradora del cuerpo en girones. Si tras su emancipación Rosaura había decidido descubrir su cuerpo, las cartas vuelven a taparlo.

Este último capítulo de la novela es relatado exclusivamente desde la mirada del estudiante de medicina, personaje que aparece solamente en este momento del relato y a quien le es dada la orden de abrir el cuerpo de la mujer, para después mantenerse, frente al cuerpo destrozado, escuchando la lectura de las cartas por parte del abogado. ¿Por qué si las cartas son las que detallan con exactitud los motivos de la muerte, las autoridades deciden primero abrir el cuerpo, descomponerlo, vaciarlo? Pareciera un desatino del autor, un elemento para remarcar el elemento trágico del relato, pero eso ya no interesa. Vale mas bien pensar que, no en vano, la relación de los motivos revelados en los escritos entre Eduardo y Rosaura le parece al estudiante «más terrible que la presencia del cadáver» por lo que trata de huir del lugar en el que se da la investigación, para "buscar un aire más respirable», pese a lo cual encuentra, a su salida, "el espectáculo de los peones que estaban recogiendo en el ataúd trozos de carne humana engangrenada.» (Riofrío, 2012, p. 41). Aquí se condensa la tensión: el cuerpo destrozado es impactante, pero el relato epistolar es aún más terrible o, tal vez, es lo suficientemente poderoso para hacer retirar los ojos sobre lo putrefacto y provocar un estado de inmunidad. Los asistentes -excepto uno- parecen entonces ser incapaces de reaccionar ante el cuerpo roto, porque el discurso los atrapa, los inmuniza del contagio, tanto como la crítica es capaz de censurar o negar la materialidad de la novela porque está atrapada en el imperativo de la escritura histórica, de la consolidación de una historia admirable, solemne y sana para la literatura nacional. No pretendo, sin embargo, delinear esa materialidad criticada como un asunto estético, basado en elementos de orden puramente lingüísticos, aunque esa sea la materialidad que a la crítica le preocupa. Al referir la materialidad, en cambio, trato de pensar en eso a lo que la imagen nos remite y no en la idea que a partir de la imagen podríamos querer construir; $\mathrm{o}$, como afirma Gisella Catanzaro, refiriéndose al diálogo benjaminiano en la propuesta de Benedict Anderson:

[...] en lugar de pretender exorcizar esas imágenes, de lo que se trata es de leerlas, de leerlas a contrapelo; lo cual significa, para Anderson, historizar esas representaciones sociales de modo tal que se vuelvan comprensibles como parte [...] de un proceso social de producción basado en relaciones de explotación, signado por las asimetrías de poder y por la lucha de clases. (Catanzaro, 2011, p. 39). 
Lo que, dicho de otro modo, nos lleva a pensar en la reacción ante esas imágenes como efecto de esa «lectura a contrapelo», reacción que nos plantea detenernos para mirar y dejarnos afectar por aquello que vemos, a partir de la información que tenemos con respecto al contexto en el que la obra se desarrolla.

Es en ese sentido que el estudiante de medicina representa un personaje clave. Aunque el relato epistolar ha logrado afectarlo más que el cuerpo desmembrado que tiene en frente, huye de él -del relato-y vuelve accidentalmente sobre el cuerpo, sobre "los trozos de carne humana engangrenada». Las imágenes que se desprenden de este momento, que constituye además las últimas líneas de la pequeña novela, se perpetúan a tal punto que en el apartado titulado «Apéndice», el narrador señala que «[E]l estudiante no ha perdido de vista lo horrible del espectáculo que tuvo delante de sus ojos y ha apuntado sus recuerdos veinte y dos años después de los sucesos.» (p. 43, énfasis añadido). De ese modo, se puede presumir que en el relato de la imagen del cuerpo en estado de putrefacción y en completa desfiguración, no solamente se refiere el leimotiv que hace de esta novela un texto al que se debe volver una y otra vez, sino que además en ese movimiento de lectura perpetua, se señala la incapacidad de ese cuerpo de llegar a ser «solemne y soportable»-y digo este llegar a ser en un sentido estrictamente hegeliano-, porque la narración de los hechos muchos años después instituye la idea de una reactualización permanente de su estado de descomposición, un estado del que aún brota la vida y que, en consecuencia, volviendo con Bataille y con Nussbaum, continúa produciendo asco. Estamos, entonces, ante una novela en la que la materialidad del cuerpo, la persistencia de su figuración a partir de la palabra que nos conduce a la imagen, se alza por sobre la misma narración en pequeños instantes relampagueantes, a medida que esos detalles logran transformarse, transfigurarse; desde las primeras páginas, la figura de Rosaura copa la imaginación de quien lee. Cito in extenso:

En la joven, su altura, flexibilidad y gentileza se ostentaban como el bambú de las orillas de su río: su tez fina, fresca y delicada la hacía semejante a la estación en que los campos reverdecen; la ceja negra, y las pupilas y los cabellos de un castaño oscuro le daban cierta gracia que le era propia y privativa: su mirar franco y despejado, una ondulación que mostraba el labio inferior como desdeñando al superior y el atrevido perfil de su nariz, daban a su rostro una expresión de firmeza inconmovible. No había una perfecta consonancia en sus facciones; por eso el conjunto tenía no sé qué de extraordinario; la limpieza de su frente y la morbidez de sus mejillas que se encendían con la emoción, parecían signos de candor: la barba perfectamente arqueada imprimía en todo su rostro cierto aire de voluptuosidad: una contracción casi imperceptible en el entrecejo mostraba haber reprimido de tiempo atrás alguna pasión violenta: el cuello levemente agobiado le daba una actitud dudosa entre la timidez y la modestia: de modo que ningún fisónomo habría podido adivinar su carácter moral y fisiológico con bastante precisión. (Riofrío 102)

La apariencia de Rosaura está fijada desde el inicio de la novela como un signo de misterio. Al mismo tiempo que percibimos la intención de describir a una mujer hermosa, ciertas huellas físicas que impiden que no haya «una perfecta consonancia en sus facciones», hacen que esa imagen se vuelva imprecisa y contradictoria, diversa y desarticulada. Es una imagen que lucha consigo misma, que logra transformarse a sí misma incesantemente, entre las huellas sosegadas como la del «mirar franco y despejado» y las mar- 
cas de alteración como aquella del «entrecejo [que] mostraba haber reprimido de tiempo atrás alguna pasión». Y, entonces, se trata de una imagen que transforma los límites del contexto en el que está siendo descrita.

Esa transformación sucede en un juego de ocultamiento/visibilización con el elemento anecdótico de la narración: el relato, que hila una historia, se detiene en los momentos en los que el cuerpo es descrito. El tiempo de la narración se suspende y entonces podemos volver a ver a Rosaura, o bien ataviada con su amenazante vestido de novia, o bien con su atuendo de heroína indómita. Luego, así como sucede al final de la novela, pareciera que el relato quisiese cubrir ese cuerpo, como alguien que recoge la capa que resbala innumerables veces de los hombros de un cuerpo sorprendente al que hay que mantener oculto. Sin embargo, cada vez que la tela se desliza y nos permite ver, ese cuerpo es distinto: vemos relampaguear una imagen que camina junto al relato poniéndolo en crisis, revelando las tensiones de su marcha y de su relación.

El intercambio epistolar leído al final de la novela por el abogado es, como dije, el último intento narrativo por cubrir ese cuerpo. La mirada del joven médico, sin embargo, deberá enfrentarse a la imagen del cuerpo que marca la tensión de toda la novela: una imagen desarticulada, aterradora y lúgubre que acosa, que persiste.

Hay un pequeño párrafo que, a manera de advertencia, da inicio al texto de Riofrío. En ese párrafo, el narrador señala:

Nada inventamos: lo que vamos a referir es estrictamente histórico: en las copias al natural hemos procurado suavizar algún tanto lo grotesco para que se lea con menor repugnancia. Daremos rapidez a la narración deteniéndonos muy poco en descripciones, retratos y reflexiones (p. 99, énfasis añadido) $)^{3}$.

La brevedad del relato, entonces, pareciera estar justificada por el afán de apurar la anécdota para que la imagen no aparezca demasiado, al menos no lo suficiente para afectar al lector y que no sienta repugnancia. Sin embargo, basta con los pequeños instantes en los que la imagen fulgura para llamar la atención de la mirada, para conmover y llevar al lector a enamorarse de Rosaura, y luego a sentir repulsión ante su cuerpo destrozado.

\section{Imágenes en resistencia}

En este caso particular, parto de una primera pregunta: si la muerte llega a tener una apariencia decente ante la que se deja de sentir asco, como sugiere Bataille, ¿cómo se entiende que la imposibilidad de este cuerpo, femenino por cierto, que no logra llegar a ese estado de "apariencia solemne y soportable", posibilite paradójicamente la consolidación de un corpus literario, es decir, la instauración del momento fundacional de una historia literaria que pretende ser, como toda historia nacional, orgánica, funcional y totalizadora? Como dije inicialmente, la instauración de este texto como documento fundacional determina esa tensión. A pesar de las lecturas más bien positivas del texto -en las que prima una interpretación optimista en torno al personaje de Rosaura como el de la mujer que se resiste a ser sometida por las leyes y determinaciones de una nación eminentemente patriarcal y religiosa desde un discurso mas bien plural-, el lugar fundacional que el relato ocupa hoy en el canon ecuatoriano pone en crisis el acto liberador de este sujeto femenino. Esto sucede porque el rol fundacional continúa legitimando una teleología que, en su linealidad, no permite percibir las imágenes de la conmoción, imágenes

3 Es de anotar el hecho de que este párrafo de advertencia no aparezca en las ediciones de 1983, 1984 ni 2003 , precedidas por las presentaciones de los críticos nombrados anteriormente. En la edición de 1984, tampoco aparece el Apéndice. 
por medio de las cuales Rosaura ejerce su poder liberador, se forja como la mujer que se emancipa. Fernando Balseca señala apropiadamente que «[L]o que en verdad emancipa Rosaura $-a$ pesar de morir en el relato- es la posibilidad de hablar desde una posición diferente de la norma; devela, además, la capacidad por la cual en este nuevo registro novelesco los personajes hablan a pesar de que sus autores, de antemano, quieren condenarlos al silencio.» (Balseca, 1996, p. 148); y es cierto, Rosaura muere «en el relato». Pero al parecer, no es solamente el autor el que pretende condenarla al silencio. El asunto es: ¿muere ella en el relato de lo nacional, en el relato historiográfico de la literatura que responde al proyecto de consolidación de la nación ecuatoriana? Si la imagen que permanece de ella es esa imagen terrible y asquerosa que el joven aspirante a médico no puede olvidar, ¿es posible que lo nacional logre instaurarse sobre un cuerpo que no logra morir del todo y, en consecuencia, que no logra solemnizarse, que no puede alzarse erguido e incólume como la piedra que da forma al cuerpo monumental del héroe patrio?

Volvamos por un momento a lo dicho por Balseca: hay, en efecto, un acto de resistencia en el que la palabra por medio de la cual Rosaura reconoce su vulnerabilidad se niega a desaparecer. Tanto se resiste a desapare- cer que, al aceptar casarse con don Anselmo, el hombre elegido por su padre, $y$ al aceptar que sea el padre y no ella quien escriba en su nombre la carta que le comunicará de su decisión a Eduardo, al momento de ser llamada para firmar, Rosaura, sin saber lo que su padre había escrito y aprovechando una breve ausencia del mismo, pone en el respaldo de la hoja un mensaje corto para Eduardo en el que le comunica sus verdaderas intenciones: «Han ocurrido cosas que me han despechado y he resuelto dar una campanada. Te juro que no seré de don Anselmo, vete a la ciudad antes del 6.» (p. 17). Como bien afirma Fernando Nina, hay un acto performativo en esa escritura clandestina, que, para este crítico, se puede interpretar como

[D]ejar atrás lo pre-escrito [...] y re-inscribir/realizar de esa manera un nuevo texto, un texto válido, un comienzo sobre la page blanche. Pero simultáneamente parece encontrarse en ese mecanismo de re-escritura también la razón del mal-entendido/ de la mala lectura de Eduardo: el mensaje al revés de la página/carta resulta también en una lectura al revés.

$Y$ se pregunta Nina (2007): "¿Qué significa esto para todo inicio literario postcolonial?» (p. 13). Pregunto yo: ¿cuál ini- cio literario?, ¿el que la crítica, a partir de la edición de 1974, ha tratado de fijar?, ¿acaso no implica esta afirmación fundacional (pos-colonial o pos-nacional), una paradoja que revela el aspecto teleológico que vuelve irremediablemente a legitimar la historia como el relato -relato moderno, cabe decir- orgánico y abarcador de la totalidad que responde a la aspiración de la consecución de un espíritu universal del que Europa es el faro? Es claro que, al reverso de la escritura que reclama un acto de resistencia, aún permanece la escritura hegemónica: el acto fundacional -el de la escritura «al revés», que para Nina funciona como metáfora de la escritura más allá de Europa, es decir, la escritura desde la periferia- se malinterpreta debido a la presencia inevitable de lo pre-escrito, la presencia de la palabra hegemónica. ¿Cómo se puede interpretar, entonces, ese «te juro que no seré de don Anselmo» que Rosaura escribe como un rugido definitivo? $\mathrm{Si}$ Rosaura, finalmente, dice el sí frente al altar porque esa aceptación la libera de padre, ¿qué es lo que logra fijar esa voluntad de no ser poseída, a pesar de haber dado su palabra? Se trata del cuerpo, de su cuerpo, porque más allá de la palabra incluso de la palabra errónea o malinterpretada que Nina percibe como fundacional- el acto de resistencia se materializa en otra performatividad: Rosaura opta por exponer su cuerpo, 
por darle figura, poniendo de relieve su libertad, para hacer corporal su voluntad de resistencia. En ese sentido, prostituirse, visto comúnmente como la total perversión del personaje y como la justificación de una muerte espantosa y trágica, en una lectura que no acentúe la narrativa histórica de la literatura nacional $-\mathrm{y}$, por lo tanto, la narrativa monumental de la misma- se transforma en la encarnación de esa resistencia que inicia con la carta malentendida. Dicho de otro modo, ante la pérdida de la palabra que no logra ser comprendida por su(s) interlocutor(es), que revela la imposibilidad de ejercer poder sobre lo dicho, la única alternativa de resistencia es la del cuerpo. ¿Resistencia a qué? Al olvido. Por lo tanto, no se trata del cuerpo-con-sentido, de aquél que forma parte «de la gran cabeza-a-cola del Animal Universal» (Nancy, 2003, p. 17), sino del cuerpo "acéfalo y sin falo» que se ubica en medio del sentido, provocando una brecha que separa cabeza de cola, como sugiere Nancy, y que si en un primer momento se prostituye $\mathrm{y}$ en un segundo momento se expone a la muerte, es porque se niega a ser parte orgánica de algo mayor, porque se niega a ser un cuerpo que hace sentido para ser mas bien un cuerpo que hace acontecimiento.

Supongamos ahora que, en una lógica mas bien lineal, de causa y efecto, cada acto de resis- tencia de Rosaura responde a una circunstancia particular de coerción. La escritura al reverso de la carta escrita por el padre, a la que Nina pone especial atención, se da en respuesta a la actitud paternal despótica que le ha impuesto el matrimonio con un hombre que no es el que ella ama. ¿A qué responde el acto de prostitución, a qué el del suicidio, ambos delimitados por la materialidad del cuerpo? El último es claramente motivado por el intercambio epistolar con Eduardo. Ahora, Rosaura puede escribirle libremente, sin ese sentido de encubrimiento de la primera carta. Sin embargo, nada queda del todo claro. Uno puede interpretar, entonces, que en esas cartas se pone de manifiesto la psicología del personaje, que demuestra su arrepentimiento por el estilo de vida que ha estado llevando y, en consecuencia, interpretar la novela entera como un triunfo de la moral por sobre ciertas virtudes políticas. No obstante, hay un detalle que pone de relieve que ese arrepentimiento es también el producto de la opresión. Rosaura aclara, en más de una oportunidad, que ella estaba «gozando» sus triunfos y que solamente la llegada de la primera carta de Eduardo le provoca avergonzarse de ellos. Afirma que si no fuera por él y el recuerdo de su madre -a quien él evoca constantementelos remordimientos «no vendrían [...] a taladrarme las entrañas» (p. 36). Lo mismo que la lleva a decir de modo contundente que «más daño me han hecho mis benefactores que mis tiranos» (p. 37). En otras palabras: el suicidio, como lo fue en otrora la huida y en un segundo momento la prostitución, es la única forma de resistirse al poder del discurso religioso y a la posibilidad de la visita de Eduardo, ahora en su papel de sacerdote que pretende salvarla. En la intención de Eduardo, podríamos descubrir la voluntad de volver a hacerla orgánica para el proyecto nacional. Según comenta Rodríguez Arenas (2009), en su segunda carta, Eduardo «[R]econfirma su sentido de superioridad para con ella, expresándolo ya no solo con el tono de sus palabras y en el tipo de mensajes que emiten, sino también al tratarla condescendientemente con la denominación 'hija mía'.» (p. LV). Así, esta mujer vuelve a resistirse al padre, a la religión, al poder que instituye el lugar del cuerpo femenino en el orden institucional del proyecto nacional.

Ahora bien, ¿a qué se resiste Rosaura al optar por la prostitución? Tanto Rodríguez Arenas como Balseca señalan la necesidad de supervivencia en una sociedad que deja desprotegidas a las mujeres que no tienen padre ni esposo. Desde un punto de vista particularmente económico, Rosaura pasaría a formar parte de una estructura de dominación de la sociedad patriarcal en la que la 
mujer debe convertir su cuerpo en mercancía. Sin embargo, la misma narración presenta una fractura entre el momento en el que ella ha logrado huir de su padre y el instante en el que se narra su vida de perversión. Entre ambos capítulos, el relato se vuelve mucho más vertiginoso -como quería el autor para evitar causar repugnancia- y no hay detalles sobre algún tipo de necesidad económica que lleve a Rosaura a optar por ese estilo de vida antes de probar otras opciones. Lo que sí hay, en cambio, es la descripción de la imagen de Rosaura como una amazona, como una mujer enigmática que, desde el inicio de la novela, no solo instaura el misterio en torno al personaje, sino una apariencia que, como la de los huesos blanqueados $\mathrm{y}$ libres de descomposición, puede describirse como solemne y soportable. Hay momentos en los que la misma narración hace de su cuerpo -que es su lugar de resistencia- un monumento imponente con el que el lector se siente reconciliado. Se trata de una imagen pre-fabricada: la de la heroína, la de la mujer valiente, la de la defensora de los oprimidos, como es descrita el día en el que deja a don Anselmo en el altar:

Llegó Rosaura en su alazán. [...] Estaba encantadora: sobre su vestido blanco de bodas se había echado una capita grana: su espesa cabellera en dos crenchas flotaba sobre la capa: su sombrerito de jipijapa sostenido por dos cintas blancas sentaba perfectamente en ese rostro encarnado por el calor y animado por la emoción. [...] (p. 24).

La imagen de la amazona es la imagen del monumento nacional. En ella logran conciliarse las opiniones de «los bandos encarnizados» que, ya sea que simpaticen con Rosaura o juzguen sus actos respaldando un castigo, reflejan el común enfrentamiento entre conservadores y liberales, en los límites de la nación. La imagen idílica de Rosaura, a pesar de aquellos detalles que imposibilitan su «perfecta consonancia», es la del cuerpo que la nación aprueba y trata de fecundar. Es la imagen erecta, de superioridad espiritual, a imagen y semejanza de lo masculino que, como bien describe Gisella Catanzaro (2011), «no se define en el prosaico mundo de los cuerpos caducos sino en el de los legados inmortales, donde la vida se muestra robusta tras la aparente caducidad» (p. 125).

No obstante esta, a pesar del entusiasmo del narrador por delinearla y sostenerla, no es la imagen que acecha. Esa imagen se esfuma ante la del cuerpo pervertido y luego desfigurado. La imagen del asedio - la que persigue al joven médico- se contrapone a la noción de lo su- blime. Quien se atrevió a verla a pesar del asco pudo rescatarla del olvido, supo darle una parcela de memoria. En ese sentido, vale preguntar entonces si la muerte de Rosaura, y su modo tétrico y repulsivo, puede ser interpretado únicamente como un castigo, como «que esa mujer mereció su muerte porque no ajustó su cara al cuerpo de la nación» (Balseca, 1996, p. 147). Ante los constantes exilios que el personaje experimenta -desde su autoexilio del sistema patriarcal hasta su suicidio- el único lugar en el que esta resistencia femenina se forja es su cuerpo. Es ese el lugar en el que algo acontece. En el cuerpo-lugar de Rosaura, recordando a Nancy, la patria se desmorona. Incluso la muerte, que pudo reivindicar su imagen otrora solemne, se resiste a ese cuerpo-sentido del que habla Nancy: la desfiguración, la desmembración, el horror de su estado de descomposición se alzan de modo perturbador para negar la pertenencia a un proyecto armónico y unificador que homogeniza, que anula. La prostitución, como antesala a su suicidio, y luego la putrefacción del cuerpo de Rosaura, diríamos entonces, son a la vez profanación de la nación y dignidad de lo imposible, performatividad del cuerpo que resiste.

La visión de ese cuerpo, sin embargo, no sería posible sin la mirada del joven médico. A diferencia de los otros espectado- 
res (el médico maestro, el abogado, el centinela, entre otros), el joven aún no ha acostumbrado su mirada hasta hacerla indolente, inmune. Pero tampoco se trata de una mirada absolutamente desprejuiciada: en ella se devela toda tensión, en ella estalla toda contradicción. La mirada del joven médico, en un primer momento, se equipara a la del crítico-historiador: hay en ella el deseo de seguir viendo en Rosaura la imagen de "su póstuma hermosura", la del cuerpo femenino que, según su criterio:

[...] debía ser, durante la vida, un incógnito misterio, radiante de gracias $\mathrm{y}$ de hechizos, y que al morir, estos secretos que tienen tanto de divino para las almas juveniles, no podían ir a hundirse en el sepulcro sin que antes tocasen las campanas sus fúnebres clamores [...] (p. 34).

Asimismo, el crítico anhela ver en el relato algo «nada desdeñable» que pueda inaugurar una tradición, y a la vez ser aclamado «con fúnebres clamores». En otras palabras, hay en la mirada del aprendiz, como en la del crítico, el deseo de no profanar el cuerpo ideal de la nación.

Sin embargo, los ojos del joven médico ya han visto la profanación y le permitieron constatar la inviabilidad de ese cuerpo; constató que, en su memoria, la imagen de ese cuerpo resistiéndose a desaparecer podía ocupar un lugar. En ese sentido, el joven médico «se compromete» con la imagen de Rosaura; como bien afirma Georges Didi-Huberman, no se trata solamente de un afán de exposición del cuerpo otro en el relato, es decir, de un comprometer la imagen del otro, sino de un «comprometerse» con él, de un desplazarse hacia ese cuerpo (Didi-Huberman, 2014, p. 196) y mirarlo para comprender «el lugar en el que esa imagen arde» (Didi-Huberman, 2013, p. 28). Esto supone, por lo tanto, que la labor del lector del presente es la de volver la mirada a pesar del asco o, incluso, asumiendo el contagio como afectación ética. La mirada del cuerpo putrefacto pone en crisis la teleología de la nación o, volviendo con Didi-Huberman, se trataría de una mirada que problematiza «el movimiento del tiempo que pasa (chronos) y que casi ha terminado de reducir ese rostro como una hoja de papel que uno arruga antes de tirarla a la basura»; o, podríamos añadir, como un monumento frío en el que nada arde y al que ya no es necesario volver a ver. Los monumentos, símbolos de lo imperecedero, son a la vez símbolos de la despersonalización del proyecto nacional. Por lo tanto, son el símbolo de lo que se eterniza como el ideal, en una lógica de posibilidad, mas no de lo que persiste en su constante peligro de imposibilidad. En oposición, esa mirada se dirigiría hacia «el tiempo que resiste (aion) y no termina de dirigir su pregunta, su súplica, su ira, su rechazo, su energía de supervivencia» (Didi-Huberman 2014, p. 37).

\section{Conclusión}

En definitiva, y tratando de abreviar todo lo dicho, si La emancipada es considerada la primera novela ecuatoriana, es porque en la construcción de esa historia monumental que transcurre hacia lo siempre posible, se necesita la piedra fundamental que sostenga un monumento cuya lógica temporal legitime su correspondencia a un espíritu universal en tanto compruebe su antigüedad, su no-haber-llegado-tan-tarde. Ante el inconformismo hacia el romanticismo paternalista de Cumandá (1879), solamente un documento anterior puede asegurar esa cronología en favor del proyecto nacional. Pero el cuerpo de Rosaura en estado de putrefacción está destinado a acechar a cada nuevo lector: aunque poco tenga ese lector qué decir sobre él, o aun cuando le adjudique solamente el sentido del castigo, la mirada que sostenga se percatará de esa imagen que impulsará la memoria y hará que sea preciso imaginar para comprobar que la historia ha enterrado muchos cuerpos que aún se resisten a desaparecer. 


\section{Referencias}

Balseca, F. (1996). En busca de nuevas regiones: la nación y la narrativa ecuatoriana. Procesos, Revista ecuatoriana de Historia, (8), 151-164.

Bataille, G. (2005). El erotismo. Barcelona: Tusquets.

Benjamín, W. ([1989] 2008). Obras. Libro I (vol. 2). Madrid: Abada Editores.

Burneo, C. (2006). El cuerpo roto. En: La cuadratura del círculo: cuatro ensayos sobre la cultura ecuatoriana. (pp. 61-116). Quito: Corporación Cultural Orogenia.

Butler, J. (2002). Cuerpos que importan: sobre los límites materiales y discursivos del "sexo”. Buenos Aires: Paidós.

Butler, J., \& Spivak, G. (2009). ¿Quién le canta al estado-nación? Lenguaje, política, pertenencia. Buenos Aires: Paidós.

Catanzaro, G. (2011). La nación entre naturaleza e historia. Sobre los modos de la crítica. Buenos Aires: Fondo de Cultura Económica.

Cervantes, M. ([1605] 1999). El ingenioso hidalgo Don Quijote de la Mancha. (A. Basante, introd.). Madrid: Anaya.

Donoso, M. (2003). Estudio introductorio. En: M. Riofrío. La Emancipada. Quito: Campaña Nacional Eugenio Espejo por el Libro y la Lectura.

Didi-Huberman, G. (2013). Cuando las imágenes tocan lo real. Madrid: Ediciones Arte y Estética.

Didi-Huberman, G. (2014). Pueblos expuestos, pueblos figurantes. Buenos Aires: Manantial.

Echeverría, E. ([1838] 1991). El matadero. En: Obras Escogidas. (B. Sarlo, estudio preliminar). Caracas: Biblioteca Ayacucho.

Nancy, J.L. (2003). Corpus. Madrid: Arena Libros.

Nina, F. (2007). La letra con sangre entra: La emancipada (1863), de Miguel Riofrío, primera novela ecuatoriana. Kipus, Revista Andina de Letras, (22), 5-21.

Nussbaum, M. (2008). El asco y las fronteras del cuerpo. En: Paisajes del pensamiento: la inteligencia de las emociones. Madrid: Paidós Ibérica.

Riofrío, M. ([1863] 2009). La emancipada (F. Rodríguez Arenas, ed.). Florida: Stockcero.

Riofrío, M. ([1863] 2012). La emancipada (D. Araújo, introd.). Quito: Libresa, Colección Antares.

Sacoto, A. (1983). Introducción. En: M. Riofrío, La emancipada. Cuenca: Publicaciones del Departamento de difusión cultural de la Universidad de Cuenca.

Sáenz, B. ([2000] 2003). Novela de la República. En: Historia de las literaturas del Ecuador, vol. 3. (D. Araújo, coord.). Quito: Universidad Andina Simón Bolívar / Corporación Editora Nacional. 